\title{
テレビにおける色再現(1) 撮像系の色設計
}

正会員藤田欣 裕 ${ }^{\dagger}$, 正会員 中野豊 之

\section{1. まえがき}

カラーテレビシステムは大きく分けると入力, 伝 送, 出力の 3 つの部分から成り立っている. 前回の講 座ではその中の伝送系における色の理論, 実際のテレ ビ方式の規格などが解説された. 今回は入力系 (カメ ラ)にかかわる色の問題とスタジオ照明について触れ る.

テレビカメラといえば，テレビが誕生したころは放 送局の一部専門家のものであったが, 現在では家庭用 のビデオカメラが普及し, 多くの人が取り扱うように なってきている．また，専門用語であったホワイトバ ランスという言葉もすでに一般的に知られた用語とな っている. 当然, ビデオカメラの色の問題についても 関心が高く, 色設計の悪いカメラの売れ行きは芳ばし くないといわれる．本講では，ビデオカメラの色設計 について，まずカメラの色再現に影響を及ぼす要因に ついて解説し, さらに具体的な放送用カメラにおける 測色計算を基礎とした色再現の検討例について紹介す る.

ビデオカメラの色再現は測色学的にベストなもの と, 好まれる色再現とは実際には異なる場合もあり, 理論通りには行かない部分もある。しかし測色学的に 基本からはずれたカメラは良い色再現性を持たないこ とは事実である。今回は測色学の基礎の部分について は, 前回までの講座を参照することとし, 具体的な事 例を取り上げ解説する。

\footnotetext{
$\dagger$ NHK 放送技術研究所

†† NHK 技術局

"Fundamentals and Applications of Color Image Processing Technology: (7)Color Reproductivity in Television Cameras" by Yoshihiro Fujita (NHK Science \& Technical Research Laboratories, Tokyo) and Toyoyuki Nakano (Engineering Administration Department, NHK, Tokyo)
}

972 (44)

\section{2. カラーテレビ系と撮像系}

カラーテレビ系における色が再現されるシステムを 模式的に図 1 に示す. 出力側に三原色を発光させる機 構があり, 入力の持つ役割すなわち撮像特性は, 被写 体のもつ色と出力のモニ夕上での色をできるだけ合わ せることである.このことは, 測色学的にいえば, 被 写体要素の画面上での色刺激を $(F)$ とすれば, 受像 側の三原色の単位量が $(R),(G),(B)$ であればモ二 夕上でのベストな色再現は

$(F)=R_{i}(R)+G_{i}(G)+B_{i}(B)$ で等色できる $R_{i}$, $G_{i}, B_{i}$ を得ることで, 実際の被写体要素の色に等し くなるように, カメラの出力がこの特性になればよ W.

被写体の分光反射率を $\rho(\lambda)$, 照明光源の分光組成 を $P(\lambda)$ とすれば

$$
\begin{aligned}
& R_{i}=c \int P(\lambda) \rho(\lambda) r d \lambda \\
& G_{i}=c \int P(\lambda) \rho(\lambda) g d \lambda \\
& B_{i}=c \int P(\lambda) \rho(\lambda) b d \lambda
\end{aligned}
$$

を満たせばよい.ただし $r, g, b$ はこの表色系に対 する三刺激值で, $c$ は比例定数である. $R_{i}, G_{i}, B_{i}$ はカメラの出力であるから, 忠実な色再現を行うには カメラの分光感度を受像三原色のスペクトル三刺激值 に合わせればよいことがわかる. 前回の講座にも示さ れているように, NTSC方式の受像側の三原色の色 度点や基準となる光源被写体の光源は規格により決め られており，それらの值を代入すればNTSC 方式の カメラの理想的な分光特性が求められる (図 2).

この三原色を元にして得られる曲線は, あるスペク トル色を再現するに必要な受像管の $\mathrm{R}, \mathrm{G}, \mathrm{B}$ 蛍光体 の輝度を示しており, 受像度の特性を直線とすれば (実際には直線ではないのでガンマ補正が必要となる が), そのまま必要な受像管の入力信号を示している. 


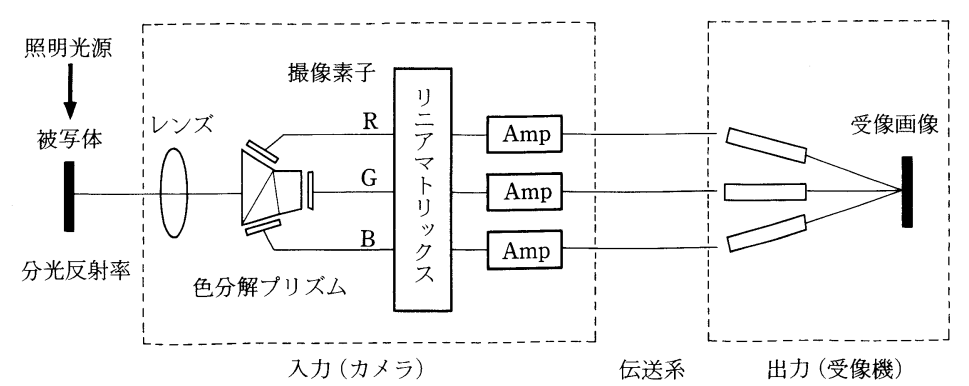

図 1 カラーテレビシステム模式図

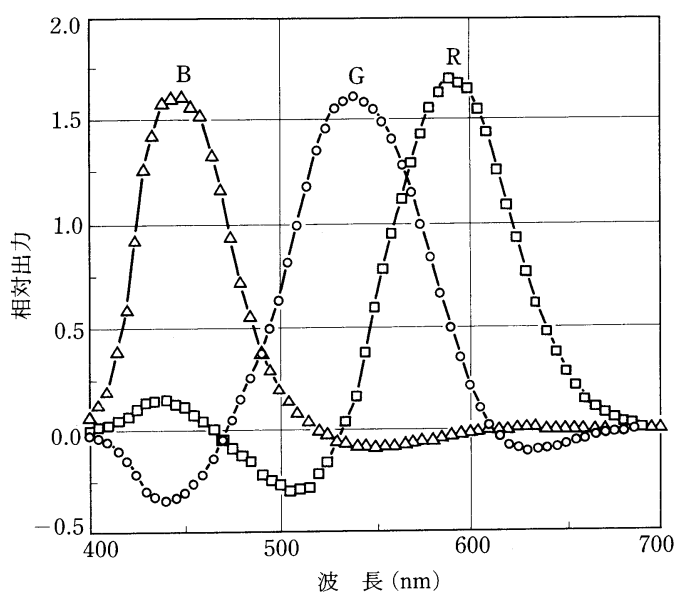

図 2 NTSC 理想撮像特性

通常の被写体の色は単一スペクトルではなく，その集 合であるから, 図 2 の特性は, 必要なカメラの出力レ ベルを示していることになる．必要なカラーカメラの 各チャンネルの出力レベルは, 各スペクトルに対する 出力レベルの積分値となる.

\section{3. カメラの色再現を決める要因}

図 1 に示すように, カメラの色再現を決める要因 は, 照明光源, レンズ, 色分解プリズム, 撮像素子の 分光特性があげられる。

\section{1 レンズ特性}

ズームレンズの分光透過特性の例を図 3 に示す．ズ ームレンズは構成枚数が多く, 光学ガラスによって短 波長の光が吸収されるので青の透過率が悪い.エクス テンダ付きや高倍率のような構成の複雑なレンズほど 影響が大きく, 青の出力が下がる.

\section{2 プリズム特性}

3 色分解光学系はプリズム面に蒸着された多層干渉 膜により行われ，図4 に示すように，それぞれBお よび $\mathrm{R}$ 反射のダイクロイック多層膜が蒸着されてい

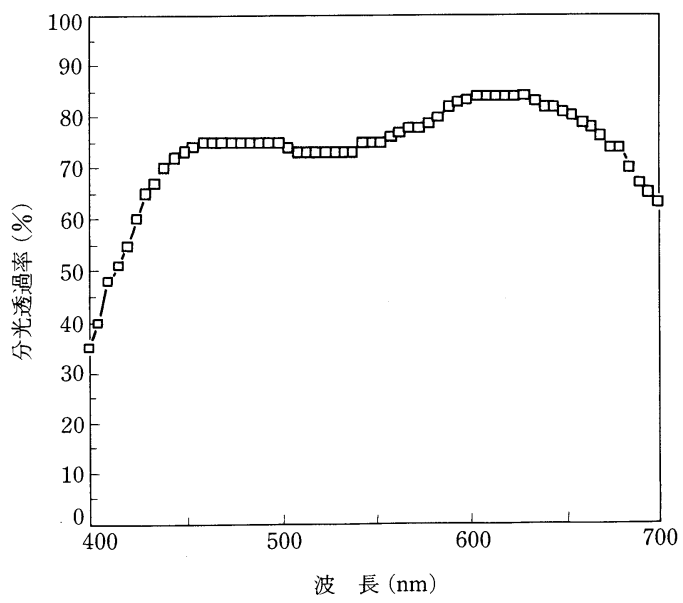

図 3 ズームレンズの分光透過特性例

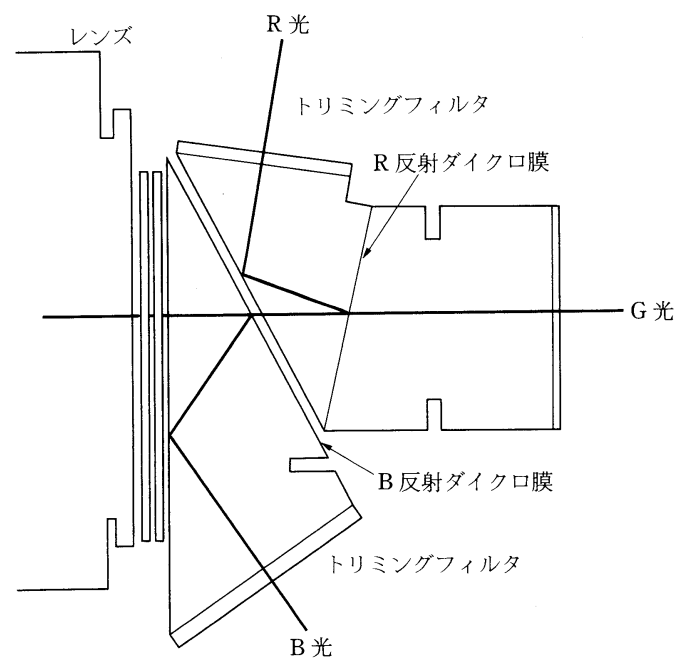

図 4 色分解プリズム系

る。これで 3 つの色信号に分解されるが，このままで はそれぞれの色特性として満足できる形状のカーブは 得られないので, トリミングフィルタや赤外カットの 


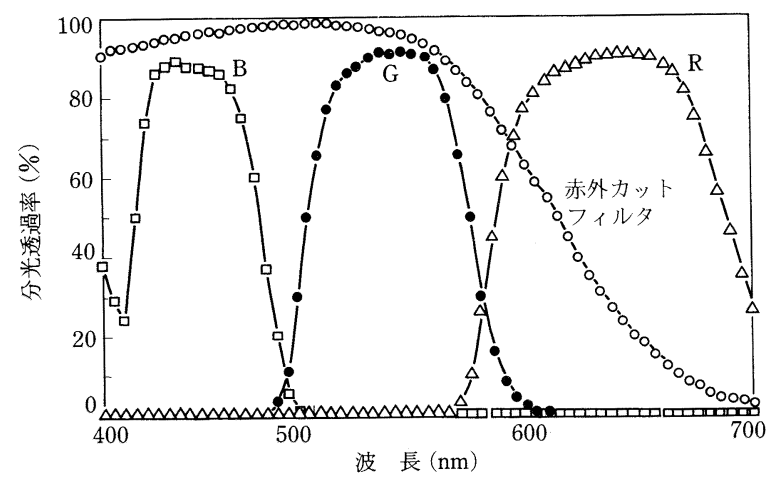

図 5 プリズム分光透過特性の例

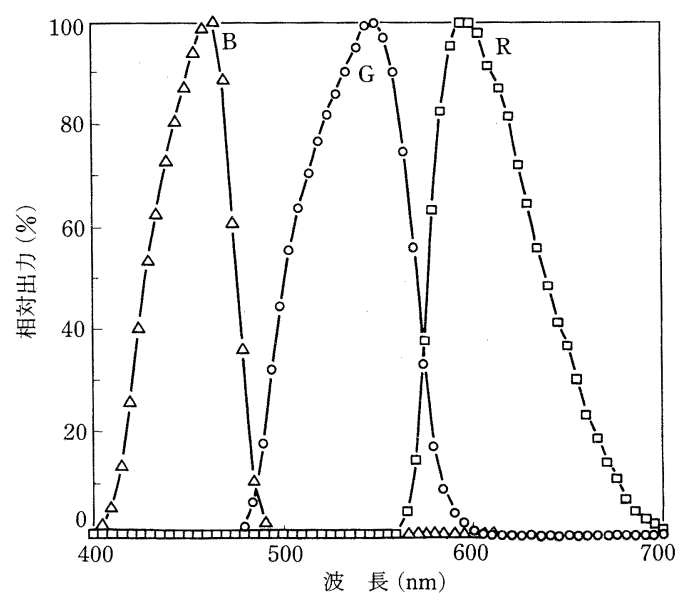

図 7 撮像素子の分光感度特性例

追加を必要とする. CCD メラ用プリズムの例を図 5 に示す.

総合的な分光特性を理想特性すなわち図 2 に近づけ るためには, 分光特性が自由に変えられることが望ま しい.そこで, このプリズムで理想特性にできるだけ 近づくように分光特性を設計する。しかし，大幅にそ の特性を理想撮像特性に合わせるために変えることは 現状，必ずしも良い選択とはいえない：カメラにおい ては感度も性能の重要なパラメータであり, 色再現を 多少犠牲にしても，感度が優先される場合が多い。こ の点については本講の意図とは異なる部分であるが， 撮像系の色設計を考える場合には重要な要素である. 例えば, CCD カメラの総合分光特性(図6)では, 青 チャンネルの分光感度特性が理想撮像特性に比べてグ リーン方向へずれている。これは CCD が短波長側の 感度が不足しているためで, 短波長側を持ち上げると その分 SN 比が劣化するからである.

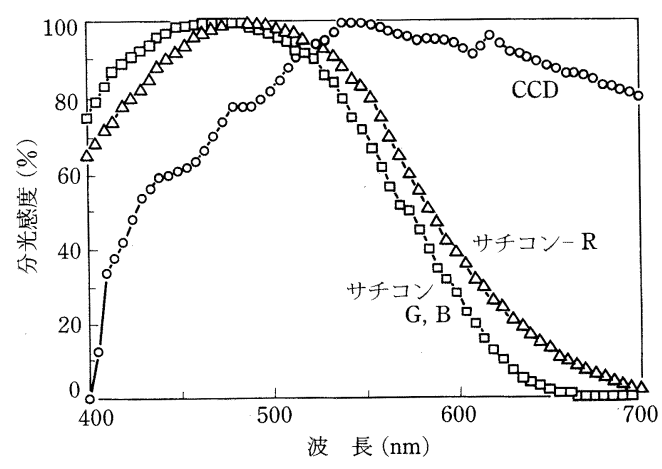

図 $6 \cdot C C D$ カメラ総合分光特性

\section{3 撮像素子特性}

サチコン管および CCD の分光感度特性を図 7 に示 す。CCDとは異なり，サチコン管は，波長による感 度の偏りが大きいため赤用の管が用意され使用され る.また CCD では分光感度特性が近赤外領域にも達 するため, 赤外カットフィルタが必要となる．撮像素 子により分光感度の形と同時に新たな要因が加わるこ とも見逃せない．赤外フィル夕は容易に変更しやすい 位置にあるため, 実際にCCD カメラでは赤側の色再 現性をこのフィルタで微調整することが多い.

\section{4 リニアマトリックス}

カメラの出力を理想撮像特性に合わせるため電子的 なマトリックス回路が使用される。すなわち $3 \times 3$ の $\mathrm{RGB}$ 三原色の 1 次変換マトリックスにより, 色再現 特性を微調整することが可能である。この変換はリニ アな領域で行う必要があり，ガンマ補正前に行う。カ メラの色設計においては重要な部分で, 細かな色再現 検討に必要とされる。

このマトリックスの決定方法として，

（1）理想撮像特性との差を色度計算し，最小 2 乗 法により求める1).

（2） ある色領域の改善が可能な係数を求める. 例 えば記憶色と関連の強い, 肌色, 緑の葉の色, 青空の色などいくつかの色を選定し，（1）の方 法により求める。

（3）熟練したオペレータが, 受像管上に再現され た色と被写体の色を直接比較しながら，最も色 誤差の少ない点を視覚的に求めてマトリックス 係数を求める.

など，さまざまな方法がある。

しかし，実際にはリニアマトリクスの効果は顕著で なく, 前述のようにカメラの他の仕様を優先させる場 合も多い. 


\section{4. 色再現性評価のための測色計算}

色再現の基礎検討には，特定の色紙を用いた測色計 算が多く用いられる。できるだけ色度座標空間に均等 に分布するように複数の色紙を選択する．あらかじめ 測定した色紙の分光反射特性をもとにカメラの色再現 座標を算出する。この時, 前述の NTSC の理想撮像 特性を同時に計算し，再現誤差を検討する ${ }^{2)}$.

赤外カットフィル夕を含めたレンズの分光特性を $L(\lambda)$, プリズムの分光特性を $P_{r}(\lambda), P_{g}(\lambda), P_{b}(\lambda)$, 撮像素子の分光感度を $S_{r}(\lambda), S_{g}(\lambda), S_{b}(\lambda)$ とする.

ランプの光源の分光特性を $A(\lambda)$, 被写体の分光反 射率を $R(\lambda)$ とした時, 撮像素子の出力は

$$
\begin{aligned}
& R=\int L(\lambda) P_{r}(\lambda) S_{r}(\lambda) A(\lambda) R(\lambda) d \lambda \\
& G=\int L(\lambda) P_{g}(\lambda) S_{g}(\lambda) A(\lambda) R(\lambda) d \lambda \\
& B=\int L(\lambda) P_{b}(\lambda) S_{b}(\lambda) A(\lambda) R(\lambda) d \lambda
\end{aligned}
$$

\section{で与えられる。}

積分の結果の $\mathrm{R}, \mathrm{G}, \mathrm{B}$ 出力は基準の白色において $1: 1: 1$ となるようにし, CIEの $X Y Z$ 座標, $x y$ 座

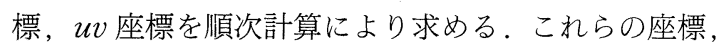
および変換方法については, 前回までの講座を参照し ていただきたい。計算結果の評価方法は現在までに 種々の方法が提案されているが, なかでもCIEが採 用しているULCS(Uniform Lightness and Chromaticuess Scale) $L U V$ 座標で評価する場合が 多い,

この座標系では距離が色再現誤差を表すため, 評価 が行いやすい.

また色再現誤差を測色計算から求める場合, 重要な 点は評価する対象の色である。

\section{5. 撮像方式と色設計}

カメラの $\mathrm{R}, \mathrm{G}, \mathrm{B}$ の色チャンネルの各出カレベル は色分解方式により, その色再現要因が異なる. 図 1 は模式的な例として各色チャンネルに各々 1つ, 合計 3 つの撮像素子を有する方式であるが，撮像系ではこ のほか, 撮像素子が 1 つの場合から, 複数(実際の例 としては 4 つまで考えられる. その方式によって色 再現の要因が異なる。

\subsection{3 板 (管)方式カメラ}

放送用のカメラとしてポピュラーなこの方式は, 最 良の色再現性を有するカメラである。

放送用カメラでは色再現性の要求が厳しい。とくに 多くのカメラを用いて番組制作を行うため, カメラ間

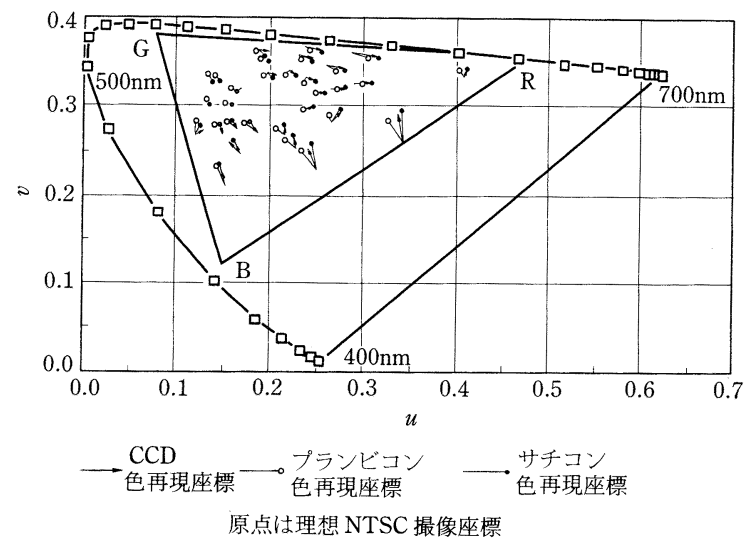

図 8 カメラによる色再現比較

で同様な色再現性が必要で, 特性を得るための管理が 重要である. 理想撮像特性に近づけることがひとつの 目標であるが, 同時にカメラの撮像素子が変わったこ とや, あるいは照明条件により, 極端に色再現性が変 わらないような考慮が必要である。

そのひとつの例として, 放送用カラーカメラの撮像 素子は, プランビコン, サチコンなどの撮像管から $\mathrm{CCD}$ 亿変遷し, 特にカメラが変わる過渡期には, その色再現の問題が表面化しやすい ${ }^{3}$. 各カメラの色 再現例を図 8 に示す. CCD カメラは比較的赤側の色 再現性に優れている.

\section{2 単板方式カメラ}

1 個の固体撮像デバイスから三原色信号を得る方式 で，2 次元に配列された画素扔のおのに色フィル夕を 重㸚合わせ，色情報を輝度情報に多重した形で取り出 す. 効率良く色分離を行い, 高解像度の輝度信号を得 るため, いわゆるミックスドハイ方式がとられてい る.さまざまな信号処理方式があり，文献 4 )などを 参考とされたい。輝度信号の低域成分は色再現に影響 するので，所定の RGB 原色成分より形成し，高域成 分は解像度に影響を与えるので, 色信号形成比は無視 して帯域を延ばしている。単板方式の色設計で重要な ことは, 色フィル夕の特性ならびに色分離方法であ る。色フィル夕については， $\mathrm{CCD}$ の表面にのせるた め製造上の制約から，フィル夕特性のばらつきなどの 問題を生じる.

単板方式の $\mathrm{R}, \mathrm{G}, \mathrm{B}$ 原色フィル夕は光の利用率が 約 $1 / 3$ と悪く, 光の利用率の良い補色フィルタが用い られることも多い(図 9, 図 10)。しかし図に示すよう に，フィルタの特性が R，Bチャンネル間で混合する 部分が生じ，色再現性は 3 板方式と比べると悪くなる (図 11). 


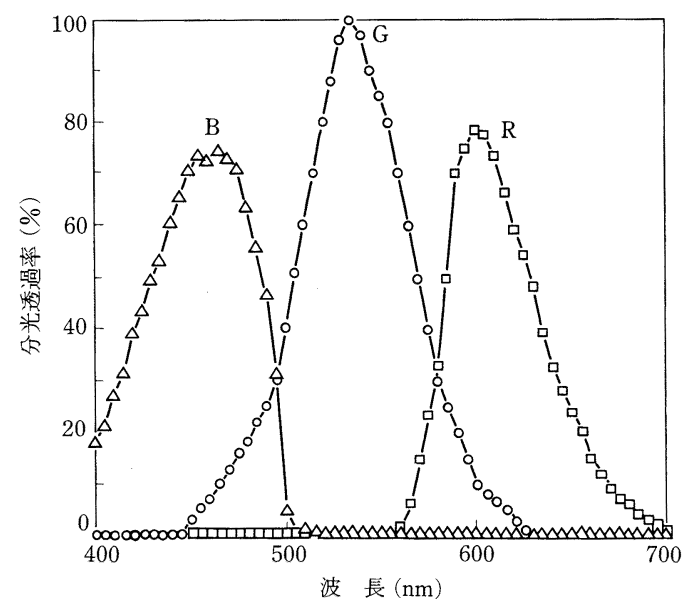

図 9 原色フィルタの分光透過特性

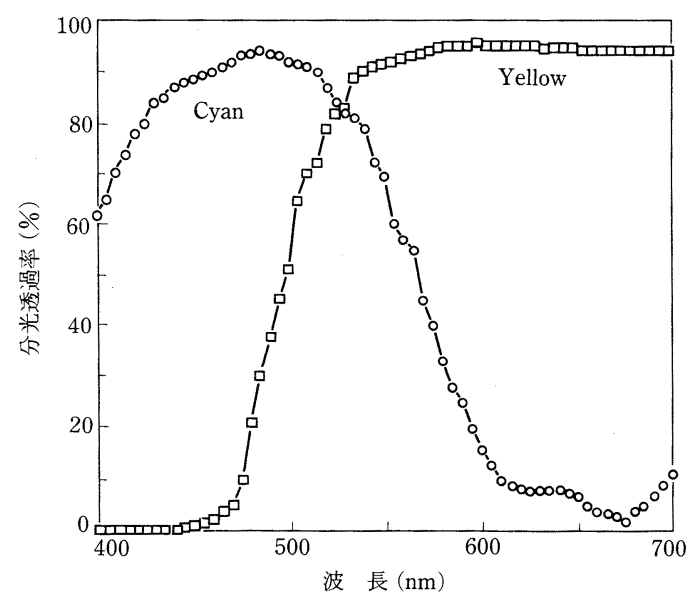

図 10 補色フィルタの分光透過特性例

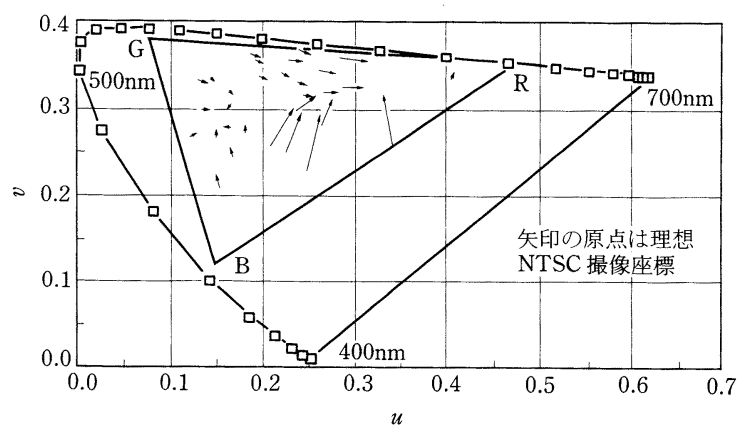

図 11 補色フィルタ方式単板カメラによる色再現例

\section{6. スタジオ照明}

近年のテレビカメラの感度の向上や CCD の開発 等, 安定性の向上によって, テレビ照明はかつてテレ ビの創世期にあったような, 照度を得ることに多くの 力をついやす作業から次第に解放され, 光の演出に関 わる作業に集中することができるようになってきた． 光の演出は, 被写体に当てる光の方向や陰影のつけ方 等, ライトセッティングによるものと, 被写体の色を どれだけ忠実に再現できるかといった，光源の選択に 関わる問題があるが,ここでは色再現に関わる問題に ついて述べることにする。

さて, 色再現の流れの中で照明の果たす役割は, 被 写体の持つ色が正確に人間の目に認識されるようにす ることであるが, テレビ照明の場合は，被写体の色が テレビカメラや受像機など, テレビのシステムを経て 人の目に認知されることになるため, それらのシステ ムの特性によっては色再現が大きく影響を受けること を認識しておく必要がある.

一般にテレビスタジオの照明に使われている光源 は, 白熱電球であるハロゲンランプがほとんどである が，テレビ照明にこうした光源が使われるのは，物体 の見え方を決定する光源の性質である演色性が高いこ とによるものである，演色性は，資料となる光源の色 温度に近い基準光源による色の見え方と資料光源によ る色の見え方を比較し，両者の色ずれの程度を定量的 に表したものであり，CIEや JISでその定量化の方法 が制定されている。

白熱電球はフィラメントをあたためて熱放射を得て いる光源であるが，この種の光源の演色性は極めて良 い. これは光源の波長成分を表す分光分布が, 可視光 域内にまんべんなくなだらかに分布している特性によ るものである。

最近では白熱電球以外にも蛍光ランプやメタルハラ イドランプ, キセノンランプといった種類の光源で, 白熱電球には及ばないものの, 演色性の比較的良い光 源が開発され，テレビの照明にも使われている。

分光特性の異なるメタルハライドランプを例に, 演 色性の違いをみてみると図 12 のようになる。

演色性の良い光源を使った場合には, 光源の色温度 に合わせてカメラのホワイトバランスを調整すること で，色再現は忠実なものとすることができる．

しかし，演色性の良くない光源を用いた場合には， テレビカメラが RGB のマスキングによる補正しか行 っていないために, 分光スペクトラムの突出や欠落に 対応する補正ができず, 破綻をきたした結果, 色再現 


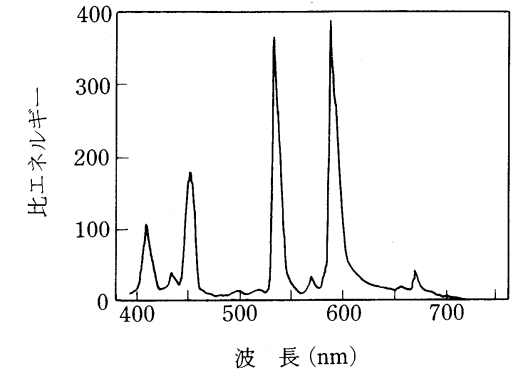

(a) $\mathrm{NaI}-\mathrm{TII}-\mathrm{Inf}_{3}$

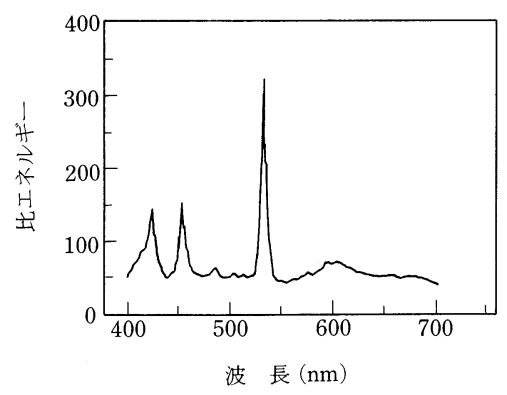

(c) $\mathrm{DyI}_{3}-\mathrm{TII}-\mathrm{Inf}_{3}$

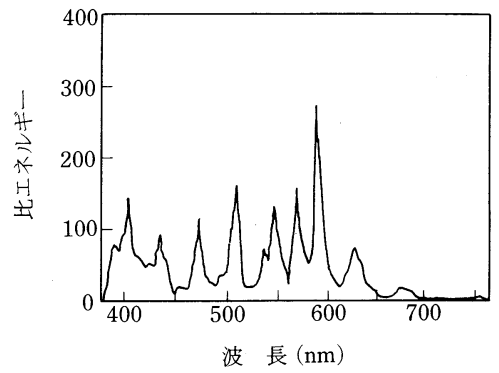

(b) $\mathrm{ScI}_{3}-\mathrm{NaI}$

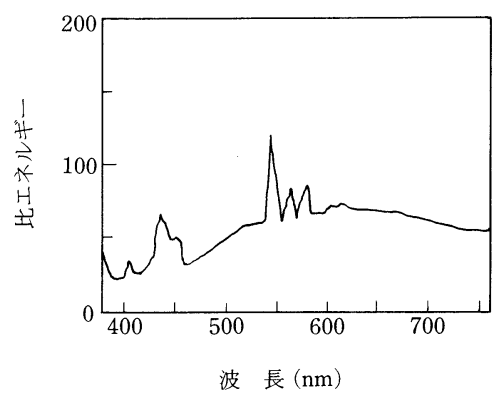

(d) $\mathrm{SnI}_{2}-\mathrm{SnBr}_{1}$

メタルハライドラナプの色温度と平均演色評価数

\begin{tabular}{lc|c|c}
\hline & 色 $\begin{array}{c}\text { 温 } \\
(\mathrm{K})\end{array}$ & $\begin{array}{c}\text { 平均演色評価数 } \\
\left(R_{e}\right)\end{array}$ \\
\hline $\mathrm{Na}-\mathrm{Tl}-\mathrm{In}$ 系 & $4200 \sim 5500$ & $65 \sim 70$ \\
$\mathrm{Sc}-\mathrm{Na}$ & 系 & $3800 \sim 4200$ & $65 \sim 70$ \\
$\mathrm{Dy}-\mathrm{Tl}$ & 系 & $4300 \sim 6000$ & 90 \\
$\mathrm{Sn}$ & 系 & 5000 & 92 \\
\hline
\end{tabular}

図 12 メタルハライドランプの特性

が一様でなくなってしまう。また，演色性の良い光源 を使った場合でも，色温度の異なる光源を同一被写体 に用いた場合，カメラのホワイトバランスに合わない 光源によって被写体の色再現の不一致が発生し, 時と して演出意図を大きく崩してしまうライティングとな ることがある。

このように,テレビ照明においては肉眼で被写体を 見る時と異なり, 記憶色による補正がテレビシステム の介在によっていったん断ち切られることになるた め, 演色性に関わる光源の選択や, ホワイトバランス に関わる色温度の違う光源の扱いについては, 特段の 注意を払う必要がある。

\section{7.むす び}

撮像系の色再現性に影響を与える要因，ならびに色 紙を用いた色計算法, また演出性に関わる照明の問題
について触れた。現状，テレビ系の色再現は実際の被 写体の色とのずれを生じている。これは, 受像機の明 るさの制約から三原色点を理想点とすることができな いことや, カメラに扔いては青感度の制約から理想特 性とはずれるなどの理由からで, 理想系からのずれは 他の特性とのトレードオフとなっている.またサチコ ンカメラと CCD カメラの色再現のように, 赤系の特 性が微妙に合わない例もある.これらの色再現性の違 いは放送用カメラとして, 現状は大きな問題となって はいない。

しかし今後, マルチメディアの発展するなか, 他の フィルム画像やスキャナから取り込んだ画像と共存す ることも多くなり, 微妙な色再現も大きな課題となっ てくると考えられる.

またテレビはハイビジョン時代を迎え, さらなる照 明光源や撮像素子の改良とともに, 被写体の色に忠実 
な色再現性をもつ撮像装置の重要性が増加する予想さ れる。

\section{〔参 考 文 献〕}

1）守田，佐藤：“カラーカメラの撮像特性と色度ひずみ”，テ レビ誌, 23, 1, pp. 44-50(1969)

2）斉藤利也: “カラーカメラの色再現”, テレビ誌, 23, 1 (1969)

3）加納, 川崎, 宮川, 牛山：“プランビコンカラーカメラの色 再現の向上”, テレビ学会方式回路研究会 (1972)

4）竹村：CCD カメラ技術, ラジオ技術社

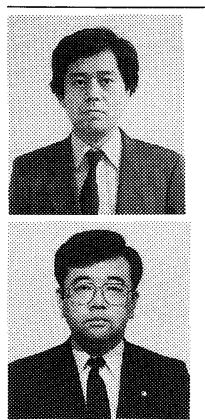

藤备 欣ひろ 裕 昭和 51 年, 東京大学工学部 電気工学科卒業. 同年, NHK に入局. 大阪 放送局を経て，56 年より，同放送技術研究 所に勤務し，現在に至る. 固体撮像素子の評 価, 固体カメラの研究に従事. 正会員.

中野 豊之 昭和 50 年, 千葉工業大学工 学部電子工学科卒業. 同年, NHK に入局. 大阪放送局，制作技術局を経て，61 年より。 技術局に勤務し，現在に至る。番組制作設備 などの開発に従事。正会員.

\section{新刊目書}

\section{信 号 処 理 工 学 一信号・システムの理論と処理技術一}

\section{今井 聖 著}

画像, 通信, 情報工学の基礎を取り扱う「テレビジョ ン学会教科書シリーズ」の第 8 弾として, ディジタル信 号処理工学の解説書がコロナ社から発行された.

本書は, 今井先生の受け持たれている大学院の授業科 目「ディジタル信号処理」の講議ノートの基礎部分を抜 粋して一部追加した内容とのことであり, 特別の予備知 識なしに気軽に読むことができる。ディジタル信号処理 の基礎が大変明解に解説されており, ディジタル信号処 理入門の教科書として好適である。

内容は, 全 11 章から構成されており, 第 1 章の信号 処理の概要説明に続き, 第 2 章と第 3 章ではアナログ (連続時間) 信号の表現方法としてフーリ工級数, 直交級 数, 解析方法としてフーリエ変換などが説明されてい る.これに続き, 第 4 章, 第 5 章では, ディジタル信号 の数学的表現として $z$ 変換, ディジタルシステムの解析 方法として離散時間システムのインパルス応答, 伝達関 数などが解説されている. 第 5 章までは信号処理の最も 基礎的な部分である.さらに, 第 6 章ではアナログ信 号の標本化とディジタル信号の再標本化の方法につい
て, 第 7 章では離散フーリエ変換とその高速演算法につ いて, 第 8 章ではディジタルフィルタの回路構成と設計 方法, 第 9 章では不規則信号の解析方法について説明さ れている.

また, 第 10 章では信号処理の具体例としての音声信 号処理について，第 11 章では画像などの 2 次元信号処 理について説明されている. 信号処理の基礎技術の解説 書とはいえ, 第 10 章では, 音声合成, 音声認識などの 具体的な応用例も述べられており，大変参考になる。第 11 章では 2 次元信号処理の基礎から, その応用例とし ての画像圧縮, 画像復元, 画像強調などについても触れ られている。

なお, 教科書という性格柄, 各章の最後には演習問題 が設定されているが, 大変詳しくかつわかりやすいその 回答例が添付されている.これは, ディジタル信号処理 を学ぶ読者にとって大変有益であり, 本書の特徵の一つ と言える.

繰り返しになるが, 本書はディジタル信号処理の基礎 が大変明解にかつ易しく解説されており, 肩を張ること なく気軽に読むことができる．この点が本書の大きなセ ールスポイントと言えよう。筆者も, 画像のディジタル 信号処理, 画像圧縮の研究開発に携わっており, 本書を 大変興味深く拝読させて頂いたが，ディジタル信号の復 習としても大いに役立った。入門者のみならず多くの 方々に読まれることを期待したい。

\section{紹介 如澤裕尚 $(\mathrm{NTT})$}

コロナ社刊 (1993 年 5 月 20 日発行), A 5 判, 214 頁 定価 2,678 円（本体 2,600 円） 